\title{
THE AEROBIC METABOLISM OF RAM SPERMATOZOA
}

\author{
T. O'SHEA AND R. G. WALES \\ Department of Veterinary Physiology, University of Sydney, \\ Sydney, N.S.W., Australia
}

(Received 18th August 1965)

\begin{abstract}
Summary. The relative contributions of fructose, lactate, acetate, citrate and inositol to the aerobic metabolism of ram spermatozoa have been examined in various combinations of these substrates. By using isotopically labelled compounds it was shown that fructose and lactate were important substrates oxidized by ram spermatozoa incubated in diluents containing fructose and low levels of other metabolites. Although the addition of sodium lactate to a spermatozoal suspension caused no change in the amount of fructose converted to lactate, there was a reduction in the amount of fructose oxidized to carbon dioxide.

At the levels of acetate and citrate occurring in semen, their effect on the oxidation of fructose by ram spermatozoa was small. Higher concentrations of these compounds, however, caused a decrease in fructose oxidation. The addition of citrate and acetate to a fructosecontaining diluent did not affect the amount of fructose utilized by ram spermatozoa. While acetate had no effect on the accumulation of lactate from fructose, the presence of the high levels of citrate decreased the amount of lactate produced.

Thus fructose and lactate are the main metabolites for unwashed ram semen incubated under aerobic conditions in a diluent containing fructose. In these circumstances, a quantitative measure of the oxidation of these substrates, coupled with an estimation of fructolysis, should give a good measure of the metabolism of the cell.
\end{abstract}

\section{INTRODUCTION}

A number of substrates occur in the seminal plasma of the ram (Mann, 1964) and, during aerobic incubations of spermatozoa in unwashed suspensions, each substrate may be oxidized to a varying extent. Little is known of the contribution of these native substrates to the overall metabolism of unwashed cells incubated in the presence of an added substrate such as fructose. Wallace $\&$ Wales (1964), using a fructose-containing medium, have shown that washing ram spermatozoa free of seminal plasma causes a reduction in the oxidation of substrates other than fructose. This is probably related to the removal of alternative substrates during washing. In the present paper, the metabolism of various combinations of substrates has been investigated, especially in relation to effects on fructose metabolism. 


\section{MATERIALS AND METHODS}

\section{Semen and diluents}

Ram semen was collected by electrical stimulation and only apparently normal ejaculates with good initial motility were used. Washed spermatozoal suspensions were obtained by diluting the semen with 10 vols. of basic diluent and centrifuging at $400 \mathrm{~g}$ for $7 \mathrm{~min}$. The supernatant was replaced with an equal volume of diluent and the spermatozoa dispersed and re-centrifuged. After removing the second supernatant, the spermatozoa were diluted to the required volume.

The basic diluent used consisted of 20 mm-mono- and di-sodium phosphate buffer ( $\mathrm{pH} \mathrm{7.0)}, 127 \mathrm{~mm}$-sodium chloride, $30 \mathrm{mg} \%$ penicillin and $50 \mathrm{mg} \%$ streptomycin. When substrates were included in the diluent, isotonicity was maintained at 308 milliosmoles/litre by decreasing the sodium chloride content. To measure substrate oxidation, isotopically labelled substrate was added to the flasks as carrier-free isotope in $0.1 \mathrm{ml}$ of $0.9 \%$ sodium chloride. Where more than one substrate was present in a diluent, duplicate or triplicate Warburg flasks were prepared for each treatment and each flask contained one labelled substrate as well as the combination of unlabelled substrates. By assay of the trapped carbon dioxide in each flask, the contribution of each substrate to the total oxygen uptake could be measured. The usual level of isotope added to a flask was $50 \mathrm{~m} \mu \mathrm{C} \mathrm{D}-\mathrm{U}-{ }^{14} \mathrm{C}$-fructose, $60 \mathrm{~m} \mu \mathrm{C}$ DL-1- ${ }^{14} \mathrm{C}$ sodium lactate, $50 \mathrm{~m} \mu \mathrm{c} \quad 1-{ }^{14} \mathrm{C}$-sodium acetate, $100 \mathrm{~m} \mu \mathrm{c} \mathrm{U}-{ }^{14} \mathrm{C}$-myo-inositol or $100 \mathrm{~m} \mu \mathrm{c} 1,5-{ }^{14} \mathrm{C}$-sodium citrate. The labelled compounds were obtained from the Radiochemical Centre, Amersham.

\section{Incubation of spermatozoa}

The experiments were carried out at $37^{\circ} \mathrm{C}$ in Warburg flasks containing carbon dioxide-free $\mathrm{KOH}(20 \% \mathrm{w} / \mathrm{v})$ in the centre well. In the first two experiments, and in the experiment with inositol, aliquots of semen were diluted in 15 vols of the appropriate diluents and $0.8 \mathrm{ml}$ incubated in $5 \mathrm{ml}$ Warburg flasks. The other experiments were carried out in double side-arm Warburg flasks of 16 to $24 \mathrm{ml}$ volume, containing $2.5 \mathrm{ml}$ of substrate diluent and $0.1 \mathrm{ml}$ of a labelled compound in the main compartment. The spermatozoal suspension $(0.3 \mathrm{ml})$ was added to the side-arm and, after temperature equilibration, was mixed with the substrate diluent. The incubation was terminated by adding $0 \cdot 1 \mathrm{ml}$ of $6 \mathrm{~N}-\mathrm{H}_{2} \mathrm{SO}_{4}$ from the other side-arm.

\section{Analytical methods}

Protein-free filtrates obtained by precipitation with equal volumes of $5 \%$ $\mathrm{w} / \mathrm{v} \mathrm{ZnSO}_{4} .7 \mathrm{H}_{2} \mathrm{O}$ and $0.3 \mathrm{~N}-\mathrm{Ba}(\mathrm{OH})_{2}$, were used to determine the initial and final levels of fructose and L-lactate. Fructose was determined by the method of Mann (1948) as modified by White (1959) and lactate by an enzymatic method outlined by Barker \& Britton (1957). The ${ }^{14} \mathrm{CO}_{2}$ was precipitated as $\mathrm{Ba}^{14} \mathrm{CO}_{3}$ and assayed for radioactivity as described by Annison \& White (1961) and corrected for self-absorption by the method of Hendler (1959). Spermatozoal counts were made in a haemocytometer. The method for the 
measurement of levels of intracellular constituents is described elsewhere (Wales \& O'Shea, 1966a).

\section{Statistical analysis}

The significance of the results has been assessed by analysis of variance, or by paired $t$-test where more appropriate. In the experiments where duplicate samples were tested, the variance between duplicates was used as error, except where the ejaculate interaction variance was significantly greater than the variance between duplicates. In the smaller experiments, pooled ejaculate interactions were used as error. In order to conserve space, the statistical analyses are not presented in the tables. Instead, the standard errors of the printed means $\left(\right.$ S.E. . $_{m}$ ) calculated from the error variance are given, with the associated degrees of freedom in parenthesis. The statistical significance of the results is quoted in the text.

\section{RESULTS}

The effect of increasing the level of lactic acid in the presence of a constant level of added fructose on the metabolism of unwashed ram semen was investigated in the first experiment. The diluents contained fructose and either no lactic acid or increasing levels of lactic acid. Added fructose plus the fructose contributed by the seminal plasma gave a mean initial fructose content of

\section{TABLE 1}

METABOLISM OF RAM SEMEN IN THE PRESENCE OF FRUCTOSE (4.4 $\mu$ MOLE/FLASK) AND VARIOUS LEVELS OF ADDED LAGTIC AGID

\begin{tabular}{c|l|l|l|l|l}
\hline $\begin{array}{c}\text { Molar ratio of } \\
\text { fructose : lactate }\end{array}$ & \multicolumn{1}{|c|}{$\begin{array}{c}\mathrm{O}_{2} \\
\text { uptake }\end{array}$} & $\begin{array}{c}\text { Fructose } \\
\text { oxidized }\end{array}$ & $\begin{array}{c}\text { Lactate } \\
\text { oxidized }\end{array}$ & $\begin{array}{c}\text { Fructose } \\
\text { utilized }\end{array}$ & $\begin{array}{c}\text { Lactate } \\
\text { accumulated }\end{array}$ \\
\hline $1: 0.5$ to 0.9 & 1.24 & 0.078 & 0.249 & 0.82 & 1.15 \\
$1: 0.9$ to 1.3 & 1.21 & 0.062 & 0.280 & 0.75 & 1.02 \\
$1: 1.8$ to 2.3 & 1.10 & 0.029 & 0.326 & 0.62 & 0.84 \\
$1: 2.6$ to 3.3 & 1.04 & 0.016 & 0.365 & 0.45 & 0.37 \\
S.E.m & $0.023(16)$ & $0.004(9)$ & $0.014(9)$ & $0.048(9)$ & $0.108(9)$ \\
\hline
\end{tabular}

All values are expressed as $\mu$ mole $/ 10^{8}$ spermatozoa over the experimental period $(2 \mathrm{hr}$ ) and are the means for four ejaculates.

$4.4 \mu$ mole/flask. Fructose to lactate ratios, calculated from assays of the diluted semen, are given in Table 1 . The results for four ejaculates $\left(3\right.$ to $7 \times 10^{8}$ cells/ flask) showed that there was a significant linear fall in oxygen uptake, fructose oxidation, fructose utilization and lactate accumulation when the concentration of lactic acid was increased $(P<0.01)$. The decrease in fructose oxidation was relatively greater than the decrease in other parameters measured, and there was a significant linear increase in lactate oxidation with the addition of lactic acid $(P<0.01)$.

Under the conditions of the above experiment, the addition of $10 \mathrm{~mm}$-lactic acid to diluted semen gave an average depression in $\mathrm{pH}$ of 0.5 units. To differentiate between the effects of $\mathrm{pH}$ and those of lactate addition, the effects $\mathrm{D}^{*}$ 
of added lactic acid (10 mM) and sodium lactate $(10 \mathrm{~mm})$ were compared with a control containing fructose as sole substrate. The mean initial fructose level was $5 \mu \mathrm{mole} /$ flask and the results for four ejaculates ( 2 to $6 \times 10^{8}$ cells/flask) are given in Table 2. The addition of sodium lactate had no effect on oxygen uptake, fructose utilization or lactate accumulation. There was a highly significant decrease in fructose oxidation, with a concomitant increase in lactate oxidation on addition of both lactic acid and sodium lactate. The addition of lactic acid caused decreases in oxygen uptake, fructose utilization and lactate accumulation.

To examine whether changes in the concentration of acetate altered the metabolism of fructose, four ejaculates of washed ram spermatozoa (4 to $8 \times$ $10^{8}$ cells/flask) were incubated in the presence of a constant level of fructose (15 $\mu \mathrm{mole} /$ flask) and either no acetate or increasing levels of sodium acetate

TABLE 2

METABOLISM OF RAM SEMEN IN THE PRESENCE OF ADDED FRUCTOSE ( $5 \mu$ MOLE/FLASK) WITH AND WITHOUT THE ADDITION OF SODIUM LAGTATE OR LACTIC ACID ( $8 \mu$ MOLE/FLASK)

\begin{tabular}{l|l|l|l|l|l}
\hline \multicolumn{1}{c|}{ Substrate added } & \multicolumn{1}{|c|}{$\begin{array}{c}\mathrm{O}_{2} \\
\text { uptake }\end{array}$} & $\begin{array}{c}\text { Fructose } \\
\text { oxidized }\end{array}$ & $\begin{array}{c}\text { Lactate } \\
\text { oxidized }\end{array}$ & $\begin{array}{c}\text { Fructose } \\
\text { utilized }\end{array}$ & $\begin{array}{c}\text { Lactate } \\
\text { accumulated }\end{array}$ \\
\hline A. Fructose & 1.23 & $0.087 \dagger$ & $0.237 \dagger$ & 0.70 & 0.98 \\
B. Fructose+Na lactate & 1.24 & 0.023 & 0.417 & 0.67 & 0.76 \\
C. Fructose+lactic acid & $0.97^{*}$ & 0.009 & 0.405 & $0.28^{*}$ & $0.37^{*}$ \\
$\quad$ S.E.m & $0.055(12)$ & $0.011(6)$ & $0.022(6)$ & $0.061(6)$ & $0.097(6)$ \\
\hline
\end{tabular}

All values are expressed as $\mu$ mole $/ 10^{8}$ spermatozoa over the experimental period ( $2 \mathrm{hr}$ ) and are the means for four ejaculates.

* C significantly different from A and B; $P<0.01$.

$\dagger$ A significantly different from $B$ and $C ; P<0.01$.

(2.5 to $15 \mu$ mole/flask). The results are shown in Table 3. Fructose oxidation was slightly decreased by low acetate concentrations and this decrease only became substantial at equi-molar concentrations of the two substrates. At the same time, these changes were reflected in an increase in the amount of acetate oxidized with increasing concentration. Statistical analyses of the results for both these parameters showed a significant quadratic, as well as a linear, component to the effect of increasing acetate content $(P<0.01)$. Although the addition of acetate had no significant effect on total oxygen uptake, it did significantly increase the oxygen uptake attributable to the combined added substrates $(P<0.01)$. The concomitant decrease in oxygen uptake not due to added substrate did not test as significant, nor was there a significant effect of acetate addition on the utilization of fructose or accumulation of lactate.

Four ejaculates of washed ram spermatozoa ( 3 to $6 \times 10^{8}$ cells/flask) were used to investigate the effects of partially replacing one substrate with an equal amount, on a carbon atom basis, of other substrate or substrates. The diluents contained $6 \mathrm{~mm}$-fructose or $12 \mathrm{~mm}$-sodium lactate or $18 \mathrm{~mm}$-sodium acetate. Where combinations were studied, equal volumes of diluents were mixed so that all flasks during incubation contained equal numbers of substrate carbon atoms. 


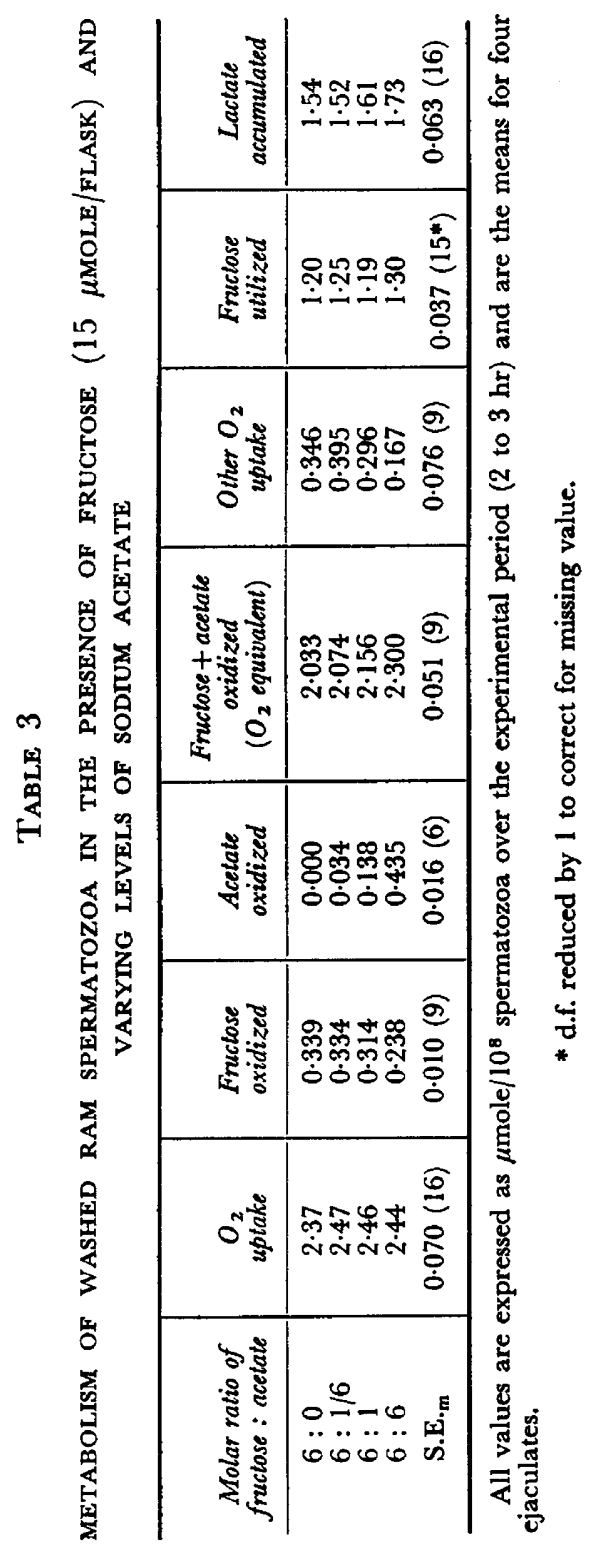


The mean results are given in Tables 4 and 5 . When fructose was partially replaced by lactate, the oxygen uptake was increased, both in the presence and absence of acetate. The amount of fructose oxidized was decreased by the inclusion of acetate or lactate, but the decrease was greater with lactate than with acetate. The amount of fructose utilized and the amount of lactate accumulated were not altered by the replacement of fructose by lactate or acetate. The replacement of lactate by fructose caused a fall in lactate oxidation (Table 5) and

TABLE 4

METABOLISM OF FRUCTOSE BY WASHED RAM SPERMATOZOA IN THE PRESENCE AND IN THE ABSENCE OF ALTERNATTVE SUBSTRATES

\begin{tabular}{|c|c|c|c|c|}
\hline Substrate added ( $\mu$ mole|flask) & $\underset{\text { uptake }}{\text { Total } \mathrm{O}_{2}}$ & $\begin{array}{l}\text { Fructose } \\
\text { oxidized }\end{array}$ & $\begin{array}{l}\text { Fructose } \\
\text { utilized }\end{array}$ & $\begin{array}{c}\text { Lactate } \\
\text { accumulated }\end{array}$ \\
\hline $\begin{array}{l}\text { A. Fructose }(15) \\
\text { B. Fructose }(7 \cdot 5)+\text { lactate }(15) \\
\text { C. Fructose }(7 \cdot 5) \text { + acetate }(22 \cdot 5) \\
\text { D. Fructose }(5) \text { + lactate }(10)+\text { acetate }(15)\end{array}$ & $\begin{array}{l}1 \cdot 32 \\
1 \cdot 44^{* *} \\
1 \cdot 30 \\
1 \cdot 45^{* *}\end{array}$ & $\begin{array}{l}0 \cdot 197 \\
0 \cdot 046^{* *} \\
0 \cdot 119 * \\
0 \cdot 044^{* *}\end{array}$ & $\begin{array}{l}0.75 \\
0.80 \\
0.64 \\
0.72\end{array}$ & $\begin{array}{l}0.78 \\
0 \cdot 63 \\
0.76 \\
0.52\end{array}$ \\
\hline S.E.m & $0.034(16)$ & $0.022(9)$ & $0.054(9)$ & $0.077(16)$ \\
\hline
\end{tabular}

All values are expressed as $\mu$ mole $/ 10^{8}$ spermatozoa over the experimental period ( $3 \mathrm{hr}$ ) and are the means for four ejaculates.

* Significantly different from A; $P<0.05$.

** Significantly different from A; $P<0.01$.

TABLE 5

OXIDATION OF LAGTATE AND ACETATE BY WASHED RAM SPERMATOZOA IN THE PRESENCE AND IN THE ABSENCE OF OTHER SUBSTRATES

\begin{tabular}{|c|c|c|c|}
\hline Substrate added ( $\mu$ molelflask) & $\begin{array}{c}\text { Lactate } \\
\text { oxidized }\end{array}$ & Substrate added ( $\mu$ molelflask) & $\begin{array}{c}\text { Acetate } \\
\text { oxidized }\end{array}$ \\
\hline $\begin{array}{l}\text { A. Lactate }(30) \\
\text { B. Lactate }(15)+\text { fructose }(7 \cdot 5) \\
\text { C. Lactate }(15)+\text { acetate }(22 \cdot 5) \\
\text { D. Lactate }(10)+\text { fructose }(5)+ \\
\text { acetate }(15) \\
\text { S.E.m }\end{array}$ & $\begin{array}{l}0 \cdot 672 \\
0.543^{*} \\
0.660 \\
\\
0.441^{* *} \\
0.037(9)\end{array}$ & $\begin{array}{l}\text { A. Acetate }(45) \\
\text { B. Acetate }(22 \cdot 5)+\text { fructose }(7 \cdot 5) \\
\text { C. Acetate }(22 \cdot 5) \text { + lactate }(15) \\
\text { D. Acetate }(15)+\text { fructose }(5)+ \\
\text { lactate }(10)\end{array}$ & $\begin{array}{l}0 \cdot 367 \\
0 \cdot 282^{*} \\
0 \cdot 270^{*} \\
0 \cdot 259^{*} \\
0 \cdot 030(9)\end{array}$ \\
\hline
\end{tabular}

All values are expressed as $\mu$ mole $/ 10^{8}$ spermatozoa over the experimental period ( $3 \mathrm{hr}$ ) and are the means for four ejaculates.

* Significantly different from A; $P<0.05$.

** Significantly different from A; $P<0.01$.

the replacement of acetate by fructose, lactate or both lactate and fructose caused a similar fall in acetate oxidation (Table 5).

The metabolism of washed ram spermatozoa ( 4 to $8 \times 10^{8}$ cells/flask) incubated for $3 \mathrm{hr}$ in the presence of fructose (15 $\mu$ mole/flask) and increasing levels of sodium citrate ( 1,3 and $9 \mu$ mole/flask) were compared with incubations in fructose alone. The results for four ejaculates are given in Table 6. Addition of citrate gave a significant linear decrease in oxygen uptake and fructose oxidation $(P<0.01)$, but no change in the oxygen uptake attributable to substrates other than fructose. Although there was no effect on fructose 
utilization, lactate accumulation was depressed by the addition of citrate, especially at the highest level. The intracellular level of isotopic carbon was measured in five ejaculates incubated for $3 \mathrm{hr}$ in a diluent containing $\mathrm{U}_{-}{ }^{14} \mathrm{C}$ fructose ( $15 \mu$ mole/flask; specific activity $6.67 \mathrm{~m} \mu \mathrm{c} / \mu$ mole) with and without the addition of sodium citrate $(9 \mu$ mole/flask). The mean concentration of isotopic carbon in the cell was found to increase significantly from $0.45 \mathrm{~m} \mu \mathrm{c} /$ $10^{8}$ cells to $0.57 \mathrm{~m} \mu \mathrm{c} / 10^{8}$ cells on the addition of citrate to the incubation med$\operatorname{ium}\left(t_{(4)}=3.24 ; P<0.05\right)$.

\section{TABLE 6}

METABOLISM OF FRUGTOSE (15 $\mu$ MOLE/FLASK) IN THE PRESENCE OF VARYING AMOUNTS OF SODIUM GITRATE

\begin{tabular}{|c|c|c|c|c|c|}
\hline $\begin{array}{l}\text { Citrate concentration } \\
(\mu \text { mole/flask })\end{array}$ & $\begin{array}{c}\text { Total } \mathrm{O}_{2} \\
\text { uptake }\end{array}$ & $\begin{array}{l}\text { Fructose } \\
\text { oxidized }\end{array}$ & $\begin{array}{l}\text { Other } \mathrm{O}_{2} \\
\text { uptake }\end{array}$ & $\begin{array}{l}\text { Fructose } \\
\text { utilized }\end{array}$ & $\begin{array}{c}\text { Lactate } \\
\text { accumulated }\end{array}$ \\
\hline $\begin{array}{l}0 \\
1 \\
3 \\
9\end{array}$ & $\begin{array}{l}2 \cdot 12 \\
2.03 \\
1.91 \\
1 \cdot 71\end{array}$ & $\begin{array}{l}0.297 \\
0.269 \\
0.251 \\
0.218\end{array}$ & $\begin{array}{l}0.35 \\
0.42 \\
0.40 \\
0.41\end{array}$ & $\begin{array}{l}1 \cdot 36 \\
1 \cdot 25 \\
1 \cdot 32 \\
1 \cdot 30\end{array}$ & $\begin{array}{l}1.52 \\
1.29 \\
1 \cdot 12 \\
0.79\end{array}$ \\
\hline S.E.m & $0.074(9)$ & $0.011(9)$ & $0.036(9)$ & $0.175(9)$ & $0.067(9)$ \\
\hline
\end{tabular}

All values are expressed as $\mu$ mole $/ 10^{8}$ spermatozoa over the experimental period ( $3 \mathrm{hr}$ ) and are the means for four ejaculates.

\section{TABLE 7}

OXYGEN UPTAKE AND RECOVERY OF RADIOAGTIVE CARBON DIOXIDE FOR RAM SPERMATOZOA INCUBATED IN THE PRESENCE OF $1-5 .{ }^{14} \mathrm{C}$ SODIUM GITRATE ( $5 \mu$ MOLE/FLASK) WITH AND WITHOUT THE ADDITION OF FRUCTOSE (5 $\mu$ MOLE/FLASK)

\begin{tabular}{l|c|c|c}
\hline \multicolumn{1}{c|}{ Substrate added } & $\begin{array}{c}\mathrm{O}_{2} \text { uptake } \\
\left(\mu \mathrm{mole} / 10^{8} \text { cells }\right)\end{array}$ & $m \mu \mathrm{c}^{14} \mathrm{CO}_{2} /$ flask & $\%{ }^{14} \mathrm{C}$ oxidized \\
\hline Nil (control) & 0.87 & 0.0 & 0.0 \\
Citrate & 0.87 & 1.453 & 2.90 \\
Citrate+fructose & $1.67 * *$ & 1.486 & 2.96 \\
$\quad$ S.E.m & $0.17(8)$ & $0.006(4)$ & $0.26(4)$ \\
\hline
\end{tabular}

All values are the means for five ejaculates and are expressed as the total change over the experimental period $(3 \mathrm{hr}$ ).

** Significantly different from control; $P<0.01$.

In the next experiment, five ejaculates of washed ram spermatozoa (10 to $15 \times 10^{8}$ cells/flask) were incubated for $3 \mathrm{hr}$ in the washing diluent, or in the presence of sodium citrate ( $5 \mu \mathrm{mole} /$ flask $)$, or in the presence of sodium citrate ( $5 \mu \mathrm{mole} /$ flask) plus fructose ( $5 \mu \mathrm{mole} /$ flask). To the flasks containing citrate, $100 \mathrm{~m} \mu \mathrm{c}$ of $1,5-{ }^{14} \mathrm{C}$-sodium citrate was added to gauge the oxidative utilization of this compound. The results are given in Table 7. The addition of citrate did not significantly alter the oxygen uptake when compared with the substrate-free incubation. Although fructose, in the presence of citrate, increased the oxygen uptake, its addition had no effect on the amount of ${ }^{14} \mathrm{CO}_{2}$ formed from the labelled citrate. 
In the final experiment, four ejaculates of washed ram spermatozoa $(7 \times$ $10^{8}$ cells/flask) were incubated for $3 \mathrm{hr}$ in the presence of myo-inositol (1 $\mu \mathrm{mole} / \mathrm{flask}$ ) and in the presence or absence of $20 \%(\mathrm{v} / \mathrm{v})$ dialysed ram seminal plasma or $20 \%(\mathrm{v} / \mathrm{v})$ dialysed fluid collected from the ewe's fallopian tube. In all flasks incubated, $0.4 \mathrm{~m} \mu \mathrm{c}$ of ${ }^{14} \mathrm{CO}_{2}$ was produced. The addition of ewe tubal fluid gave an increase in the oxygen uptake, but had no effect on the ${ }^{14} \mathrm{CO}_{2}$ produced.

\section{DISCUSSION}

It is now generally accepted that the in-vitro metabolism of spermatozoa in several mammalian species is predominantly of a glycolytic nature (Mann, 1964). Although the source of energy in washed spermatozoa incubated without added substrate is plasmalogen (Hartree \& Mann, 1959, $1960 \mathrm{a}, \mathrm{b}, 1961$ ), the breakdown of phospholipid has not been shown to occur in semen in the presence of fructose. The respiratory quotient of I for ram semen obtained in the presence of fructose and lactate (Wales \& O'Shea, 1966b) emphasizes the glycolytic nature of ram spermatozoal metabolism.

Fructose is the main free sugar of ram semen (Mann, 1964). Terner \& Korsh (1962) have shown that spermatozoa are able to convert carbohydrate to lipids, but any nett synthesis of lipids from fructose must be of a minor nature, as fructose disappearing is nearly quantitatively accounted for as lactate and sorbitol accumulated and $\mathrm{CO}_{2}$ formed (O'Shea \& Wales, 1965). Sorbitol occurs in ram semen, but, in the presence of added fructose, does not materially contribute to the cell metabolism (O'Shea \& Wales, 1965). Glycerylphosphorylcholine, although present in ram seminal plasma, only enters spermatozoal metabolism in the presence of enzymes of the female genital tract (White \& Wallace, 1961). The occurrence of pyruvic acid in semen is in doubt (Mann, 1964).

In semen, glycolysis leads to a decrease in hexose concentration and an increase in the level of lactic acid (Mann, 1946; Scott, White \& Annison, 1962a). As shown in the present paper, changes in the level of lactic acid in semen alter the amount of fructose oxidized to $\mathrm{CO}_{2}$. Thus, in the presence of physiological levels of lactate, the use of isotopically labelled fructose does not measure total substrate oxidation and lactate oxidation must also be considered. Changes in lactate concentration do not alter the rate of conversion of fructose to lactate unless the $\mathrm{pH}$ falls, in which case all indices of metabolism are decreased.

Fructose and lactic acid are probably oxidized to $\mathrm{CO}_{2}$ by way of the Krebs' tricarboxylic acid cycle (Salisbury \& Lodge, 1962). Scott, White \& Annison (1962b) obtained suppression of acetate oxidation in ram spermatozoa by fluoroacetate, suggesting acetate also is oxidized by way of this cycle. As observed by Scott et al. (1962a), the addition of acetate decreased the oxidation of hexose. In the present studies, this decrease was less than with similar additions of lactate. This difference may be due to lactate forming a metabolic pool in the pathway of fructose utilization, while acetate acts as a competitor at the tricarboxylic level, or secondly it may be due to differences in availability 
of the two compounds inside the cell. At comparable acetate levels to those occurring in ram semen (Scott, White \& Annison, 1961), only a very small depression in fructose oxidation occurred and thus the oxidation of acetate in ram semen diluted with a fructose-containing diluent would not be a major source of energy.

The present results support the finding of Lardy \& Phillips (1942) that citrate decreases the oxygen consumption of spermatozoa. The observation (I.C.A. Martin, unpublished data) that the addition of $10 \mathrm{~mm}$-citrate depresses the motility and percentage motile in ram spermatozoa stored for 4 days at $5^{\circ} \mathrm{C}$ may be related to the depression in metabolism which occurs on the addition of citrate. At the level of citrate comparable to that present in semen diluted for metabolic experiments, however, the decrease in oxygen uptake and fructose oxidation is small and unimportant. As found by Humphrey \& Mann (1949), fructose utilization was unaltered by citrate addition. However, high concentrations of added citrate depressed lactate accumulation. This depression in the conversion of fructose to lactate in the presence of citrate could be related to the reported inhibition of phosphofructokinase by citrate (Garland, Randle \& Newsholme, 1963; Parmeggiani \& Bowman, 1963; Passonneau \& Lowry, 1963). The finding that the addition of citrate to the diluent for spermatozoa increased the concentration of intracellular labelled carbon in the presence of labelled fructose, indicates that a similar mechanism may operate in spermatozoa and lead to the accumulation of hexose phosphate in the cell.

In the experiment with labelled citrate, little citrate was oxidized and thus its oxidation neither compensates for any reduction in fructose oxidation nor materially adds to the oxygen uptake when fructose is present. As found by Humphrey \& Mann (1949), the addition of sodium citrate to washed ram spermatozoa incubated without added substrate had no effect on oxygen uptake and the additional oxygen needed for citrate oxidation is probably too small to be measured by the methods used.

Inositol, which is present in the genital tract secretions of the female rabbit (Gregoire, Gongsakdi \& Rakoff, 1962) and in seminal plasma (Mann, 1951, 1954; Hartree, 1957), is formed from glucose in the rat testis and seminal vesicles (Eisenberg, Bolden \& Loewus, 1964; Imai, 1964). The fact that the ${ }^{14} \mathrm{CO}_{2}$ produced in the experiment with inositol was at the same low level in all flasks suggests that it may have been formed from a minor impurity in the ${ }^{14} \mathrm{C}$-inositol. Thus no, or very little, $\mathrm{CO}_{2}$ was formed from inositol in the presence of ram semen, with or without the addition of fluid obtained from the fallopian tube. Since the secretions of the fallopian tube did not affect the oxidation of inositol, it is unlikely that any enzymatic conversion of seminal inositol to a substrate for spermatozoa occurs in this part of the female genital tract.

From the foregoing experiments it may be concluded that, in the presence of added fructose, fructose and lactate are the main metabolites for unwashed ram spermatozoa under aerobic conditions. A quantitative measure of their oxidative metabolism can be obtained by using duplicate flasks for each treatment, one containing labelled fructose and the other labelled lactate. Assay 
of radioactivity from these flasks coupled with an estimation of fructolysis should give a measure of the overall metabolism of ram spermatozoa.

\section{ACKNOWLEDGMENTS}

The authors are indebted to Professor C. W. Emmens for interest and criticism, and to Mr B. J. Restall for the donation of fallopian tube fluid. This work was aided by grants from the Rural Credits Development Fund of the Commonwealth Bank of Australia and the Australian Wool Board. One of us (T.O'S.) was supported by a Walter and Eliza Hall Research Fellowship.

\section{REFERENCES}

Annison, E. F. \& White, R. R. (1961) Glucose utilization in sheep. Biochem. 7. 80, 162.

Barker, J. N. \& Britton, H. G. (1957) The enzymatic estimation of $\mathrm{L}(+)$ lactic acid. F. Physiol., Lond. 136, 3P.

Eisengerg, F., Bolden, A. H. \& Loewus, F. A. (1964) Inositol formation by cyclization of glucose chain in rat testis. Biochem. biophys. Res. Commun. 14, 419.

Garland, P. B., Randle, P. J. \& Newsholme, E. A. (1963) Citrate as an intermediary in the inhibition of phosphofructokinase in rat heart muscle by fatty acids, ketone bodies, pyruvate, diabetes and starvation. Nature, Lond. 200, 169.

Gregorre, A. T., Gongsakdi, D. \& Rakoff, A. E. (1962) The presence of inositol in genital tract secretions of the female rabbit. Fert. Steril. 13, 432.

HARTREe, E. F. (1957) Inositol in seminal plasma. Biochem. 7. 66, 131.

HARTreE, E. F. \& MANN, T. (1959) Plasmalogen in ram semen and its role in sperm metabolism. Biochem. F. 71, 423.

Hartree, E. F. \& Mann, T. (1960a) Phospholipids in mammalian semen. F. Reprod. Fert. 1, 23.

HARTREe, E. F. \& MANN, T. (1960b) Crystalline lysoplasmalogen (lysophosphatidal choline): preparation from heart muscle and action on erythrocytes and spermatozoa. Biochem. 7. 75, 251 .

Hartree, E. F. \& ManN, T. (1961) Phospholipids in ram semen: metabolism of plasmalogen and fatty acids. Biochem. F. 80, 464.

HeNDLER, R. W. (1959) Self absorption correction for carbon 14. Science, 130, 772.

Humphrey, G. F. \& MANN, T. (1949) Studies on the metabolism of semen. 5. Citric acid in semen. Biochem. F. 44, 97.

ImAt, Y. (1964) Biosynthesis of myo-inositol in rat seminal vesicles and prostates. Biochem. 7. 55, 126.

Lardy, H. A. \& Phillips, P. H. (1942) The relation of certain fundamentals of sperm metabolism to the problem of semen storage for artificial insemination. 7. Anim. Sci. 1, 344.

ManN, T. (1946) Studies on the metabolism of semen. 3. Fructose as a normal constituent of seminal plasma. Site of formation and function of fructose in semen. Biochem. F. 40, 481.

Mann, T. (1948) Fructose content and fructolysis in semen. Practical application in the evaluation of semen quality. F. agric. Sci. 38, 323.

MANN, T. (1951) Inositol, a major constituent of the seminal vesicle secretion of the boar. Nature, Lond. $168,1043$.

MANN, T. (1954) On the presence and role of inositol and certain other substances in the seminal vesicle secretion of the boar. Proc. $R$. Soc. B, 142, 21.

ManN, T. (1964) The biochemistry of semen and of the male reproductive tract. Methuen, London.

O'SheA, T. \& Wales, R. G. (1965) Metabolism of sorbitol and fructose by ram spermatozoa. $\mathcal{F}$. Reprod. Fert. 10, 353.

Parmeggiani, A. \& Bowman, R. H. (1963) Regulation of phosphofructokinase activity by citrate in normal and diabetic muscle. Biochem. biophys. Res. Commun. 12, 268.

Passonneau, J. V. \& Lowry, O. H. (1963) P-fructokinase and the control of the citric acid cycle. Biochem. biophys. Res. Commun. 13, 372.

Salisbury, G. W. \& Lodge, J. R. (1962) Metabolism of spermatozoa. Adv. Enzymol. 24, 35.

Scott, T. W., WhITE, I. G. \& ANNIson, E. F. (1961) Fatty acids in semen. Biochem. 7. 78, 740.

Scotr, T. W., White, I. G. \& Annison, E. F. (1962a) Glucose and acetate metabolism by ram, bull, dog and fowl spermatozoa. Biochem. $\mathbf{7 . ~ 8 2 , ~} 398$.

Scott, T. W., White, I. G. \& Annison, E. F. (1962b) Oxidation of short-chain fatty acids $\left(\mathrm{C}_{\mathbf{1}}-\mathrm{C}_{\mathbf{8}}\right)$ by ram, bull, dog and fowl spermatozoa. Biochem. 7. 83, 392. 
TERner, C. \& Korsh, G. (1962) The biosynthesis of $\mathrm{C}^{14}$-labelled lipids by isolated bull spermatozoa. Biochemistry, 1, 367.

Wales, R. G. \& O'SheA, T. (1966a) The oxidative utilisation of fructose and acetate by washed ram spermatozoa in the presence or absence of potassium and magnesium. Aust. F. biol. Sci. (In press).

WALEs, R. G. \& O'SHEA, T. (1966b) Effect of low levels of carbon dioxide on the metabolism of ram and bull spermatozoa. F. Reprod. Fert. 11, 171.

WALLACE, J. C. \& WALES, R. G. (1964) Effect of ions on the metabolism of ejaculated and epididymal ram spermatozoa. 7. Reprod. Fert. 8, 187.

WhITE, I. G. (1959) Studies on the estimation of glycerol, fructose and lactic acid with particular reference to semen. Aust. 7. exp. Biol. med. Sci. 37, 44.

White, I. G. \& WALlace, J. C. (1961) Breakdown of seminal glycerylphosphorylcholine by secretions of the female reproductive tract. Nature, Lond. 189, 843. 